Article

\title{
The Influence of Wheat Malt Quality on Final Attenuation Limit of Wort
}

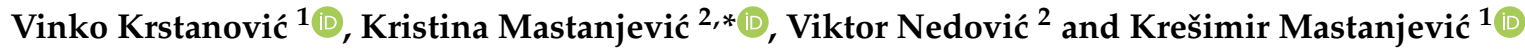 \\ 1 Josip Juraj Strossmayer University of Osijek, Faculty of Food Technology Osijek, F. Kuhača 20, 31000 Osijek, \\ Croatia; vkrstano@ptfos.hr (V.K.); kmastanj@gmail.com (K.M.) \\ 2 University of Belgrade, Faculty of Agriculture, Zemun, Serbia; viktor.nedovic@mpn.gov.rs \\ * Correspondence: kristinahabschied@gmail.com; Tel.: +385-31-224-411
}

Received: 6 September 2019; Accepted: 29 September 2019; Published: 30 September 2019

check for updates

\begin{abstract}
This paper aimed to investigate the influence of certain wheat and wheat malt quality indicators on limit of attenuation of wort (LAT). The experiment was conducted using wheats that have been proven to display the best malting properties with heightened total and soluble $\mathrm{N}$ and very good viscosity. Standard micromalting and brewing processes and analysis were applied. The obtained results showed that the quality of analyzed malts was satisfying. Statistical analysis determined no significant correlation between the limit of attenuation of wort and any of the other analyzed quality indicators. The lack of close correlations between indicators is probably due to the extremely complex intertwine of factors influencing the LAT, pointing to the fact that this particular indicator should be observed as separate and mainly variety-dependent.
\end{abstract}

Keywords: wheat; malt quality; limit of attenuation; wort

\section{Introduction}

In the production of beer, the real degree of fermentation (RDF) is an important indicator of brewery production, its consistency, and profitability, since it determines the yield of alcohol in the brewing process as well as malt fermentation efficiency. RDF describes the proportions of fermentable wort carbohydrates (extracted from malted barley) that are converted into carbon dioxide and ethanol by the fermenting yeast [1]. Limit of attenuation of congress wort (LAT), a relatively simple and efficient method for the determination of fermentable extract, is also a good indirect indicator of RDF. However, due to the absence of maltose rest in industrial conditions, RDF and LAT results are not comparable. Nevertheless, there is a strong positive correlation with the RDF values of industrially obtained wort (for barley malt $r=+0.83$ ) [2]. The precondition required for high LAT values (and subsequently high $\mathrm{RDF}$ ) is the optimal wort composition regarding the yeast's requirements for nutrients and energy. Thus, wort with a high content of fermentable extract has to contain well balanced high amounts of sugars and amino acids available to yeasts. All this is enabled by the kernel's ability to be modified and its potential for enzyme synthesis. This subject matter has been well investigated for barley malts, but even in traditionally brewing countries, there are very few wheat varieties intentionally selected for wheat malt production. According to the German professional classification, such varieties are usually classified as B varieties or "brauweizen" [3], but very often starchy C varieties, which have shown good malting properties (Armada, Elixer, etc.) are also used in wheat beer production. Fermentability can be influenced by numerous factors: variety, genetics, phenotype; process parameters during malting, and mashing also contribute to the fermentability. All these factors intertwine and influence each other in an extremely complicated series of events. It is considered that final attenuation is influenced by variety (about $58 \%$ ), malting technique (32\%), and other factors (11\%) [4]. This is why it is very hard to unambiguously relate fermentability with any of the quality indicators, and it can be considered 
as a separate (and cumulative) quality indicator. Nevertheless, a significant number of papers have emerged lately and have provided better insight about wheat as a malting cereal. A review paper by Faltermaier et. al. [5] refers to many of these. The estimation of the malting quality of wheat varieties is a common problem partially due to the "forced maturation" phenomenon. This phenomenon is more pronounced in the South-Eastern parts of Europe where the effect of force maturation limits the selection and labelling of wheat varieties intended for malting. Forced maturation of grains occurs when there is high air humidity and high temperatures during the grain filling phase. It has serious and unfavorable effects on numerous cereal quality indicators, mainly on the protein component which is greatly influenced by the environmental conditions [6]. The aim of this paper was to investigate the possibility of predicting LAT values in wort based on values of certain wheat and wheat malt quality indicators (or group of indicators). The influence of certain quality indicators on LAT was also studied for the correlation strength between them.

\section{Materials and Methods}

\subsection{Wheat Samples}

Wheat varieties with suitable malting properties were chosen according to the preliminary three-year research [7] during which a total of 32 wheat varieties were tested. The tested varieties originated from the Agricultural Institute Osijek and Bc Institute for Plant Breeding and Production Zagreb. The obtained results enabled the classification of malting wheat varieties into the malting quality groups [3]. The results of preliminary research showed that most varieties including the seven (1-Lucija; 2-Srpanjka; 3-Panonka; 4-Barbara; 5-Žitarka; 6- Ana; 7-Contur) that showed the best results as malting varieties had an increased total $\mathrm{N}$ share. This resulted in the increased total $\mathrm{N}$ share $(<730 \mathrm{mg} / \mathrm{L})$ in wheat malt, increased soluble $\mathrm{N}$ in wort, and excellent viscosity (1.65 mPaxs). All this classifies them as the second quality group. Varieties 1-6 are typical domestic bread wheat varieties belonging to group $\mathrm{A}$, while variety 7 is feed variety and belongs to group $\mathrm{C}$, according to the German testing protocol [8]. Based on the values for soluble $\mathrm{N}$ and Kolbach number, the saturation of wort with soluble $\mathrm{N}$ during the mashing was noted. This was partially a positive thing because the obtained values seemed to be lower than expected based on the starting $\mathrm{N}$ values in malt. These wheats showed a strong negative correlation, for all three seasons, between viscosity and extract. However, between viscosity and filtration speed, a strong negative correlation was established. Furthermore, a strong positive correlation between viscosity, speed of filtration, hardness and vitreosity of grains, total and soluble pentosans was determined. The same experiment with wheat malt brought out LAT values that differed (in some cases significantly) by individual quality indicators. However, some varieties whose malts showed similar values for individual indicators resulted in different LAT values.

\subsection{Wheat Grain and Micro-Malting Quality Tests}

Table 1 shows the determined quality indicators of the chosen wheat samples. All analyses were done according to the EBC (European Brewery Convention) and MEBAK (Mitteleuropäischen Brautechnischen Analysenkommission) methods [9,10], except for the total and soluble pentosans that were determined according to Hashimoto et. al. [11]. Ten kilos of each wheat variety (season 2017/2018) (Table 1) was collected as untreated and conditioned grain, scaled, and packed into double-walled paper bags $(1 \mathrm{~kg})$. To overcome the post-harvest grain dormancy, the material was stored for two months in a dry and cool place $\left(20^{\circ} \mathrm{C}\right)$, until the micromalting took place. To avoid the influence of microbiological contamination on malt quality, raw material control concerning Fusarium graminearum and Fusarium culmorum contamination was conducted, according to the MEBAK procedure (Method 2.6.). Micromalting was conducted in Seeger micromaltery according to the standard MEBAK procedure (Method 2.5.3.1) with slight corrections regarding air humidity during dry steeping (85\%) and germination phase. This was necessary because the wheat grains, due to the absence of husk, are able to retain more water with regard to barley. Moisture was controlled at the beginning of the third 
day, every hour soaking under water, until the moisture content of $44.5 \%$ was achieved. Moisture was adjusted with spray steeping in a germination box (first day of germination). After micromalting, the degermination was performed manually. Malt was stored for one month in order to stabilize the moisture content. Quality indicators were followed during micromalting and are shown in Table 2.

Table 1. Results of the wheat analysis.

\begin{tabular}{cccccccc}
\hline & \multicolumn{7}{c}{ Varieties } \\
\cline { 2 - 7 } & $\mathbf{1}$ & $\mathbf{2}$ & $\mathbf{3}$ & $\mathbf{4}$ & $\mathbf{5}$ & $\mathbf{6}$ & $\mathbf{7}$ \\
\hline 1000 grain weight (g) & $35.4^{\mathrm{e}}$ & $35.1^{\mathrm{e}}$ & $36.4^{\mathrm{d}}$ & $39.4^{\mathrm{b}}$ & $38^{\mathrm{c}}$ & $32.9^{\mathrm{f}}$ & $40.5^{\mathrm{a}}$ \\
\hline Total N (\% s.tv.) & $2.47^{\mathrm{cd}}$ & $2.22^{\mathrm{e}}$ & $2.44^{\mathrm{d}}$ & $2.62^{\mathrm{a}}$ & $2.58^{\mathrm{b}}$ & $2.48^{\mathrm{c}}$ & $1.98^{\mathrm{f}}$ \\
\hline Total proteins (\% d.wt.) & $15.44^{\mathrm{cd}}$ & $13.88^{\mathrm{e}}$ & $15.25^{\mathrm{d}}$ & $16.38^{\mathrm{a}}$ & $16.13^{\mathrm{b}}$ & $15.50^{\mathrm{c}}$ & $14.37^{\mathrm{f}}$ \\
\hline NIR-HD grain hardness & $58^{\mathrm{c}}$ & $58^{\mathrm{c}}$ & $59^{\mathrm{b}}$ & $60^{\mathrm{a}}$ & $60^{\mathrm{a}}$ & $59^{\mathrm{b}}$ & $54^{\mathrm{d}}$ \\
\hline Total pentosans (\% d.wt.) & $7.24^{\mathrm{c}}$ & $7.29^{\mathrm{c}}$ & $6.88^{\mathrm{d}}$ & $7.85^{\mathrm{b}}$ & $7.85^{\mathrm{a}}$ & $7.19^{\mathrm{c}}$ & $6.71^{\mathrm{e}}$ \\
\hline Soluble pentosans (\% d.wt.) & $0.73^{\mathrm{b}}$ & $0.69^{\mathrm{c}}$ & $0.59^{\mathrm{e}}$ & $0.68^{\mathrm{d}}$ & $0.68^{\mathrm{c}}$ & $082^{\mathrm{a}}$ & $0.66^{\mathrm{d}}$ \\
\hline Vitreosity (\%) & $24^{\mathrm{e}}$ & $28^{\mathrm{c}}$ & $18^{\mathrm{g}}$ & $58^{\mathrm{a}}$ & $58^{\mathrm{a}}$ & $26^{\mathrm{d}}$ & $19^{\mathrm{C}}$ \\
\hline
\end{tabular}

Values are the mean obtained with three measurements. Values displayed in the same lines and tagged with different letters $(\mathrm{a}-\mathrm{g})$ are significantly different $(p<0.05)$.

Table 2. Correlation between the quality indicators and limit of attenuation (LAT) for the test wheat (Pearson correlation matrix).

\begin{tabular}{ccccccccc}
\hline & P-1 & P-2 & P-3 & P-4 & P-5 & P-6 & P-7 & P-25 \\
\hline P-1 & 1 & $-\mathbf{0 . 2 0 6 0}$ & -0.3920 & -0.3913 & -0.3939 & 0.2817 & -0.2472 & -0.1406 \\
P-2 & -0.2060 & 1 & $\mathbf{- 0 . 2 4 8 2}$ & $\mathbf{- 0 . 2 4 7 2}$ & $\mathbf{- 0 . 2 4 8 4}$ & -0.1227 & $\mathbf{- 0 . 3 5 2 3}$ & -0.3095 \\
P-3 & -0.3920 & -0.2482 & 1 & $\mathbf{1 . 0 0 0 0}$ & $\mathbf{1 . 0 0 0 0}$ & 0.6170 & $\mathbf{0 . 9 3 8 5}$ & -0.3329 \\
P-4 & -0.3913 & -0.2472 & $\mathbf{1 . 0 0 0 0}$ & 1 & $\mathbf{1 . 0 0 0 0}$ & 0.6179 & $\mathbf{0 . 9 3 8 5}$ & -0.3340 \\
P-5 & -0.3939 & -0.2484 & $\mathbf{1 . 0 0 0 0}$ & $\mathbf{1 . 0 0 0 0}$ & 1 & $\mathbf{0 . 6 1 6 1}$ & $\mathbf{0 . 9 3 8 1}$ & -0.3326 \\
P-6 & 0.2817 & -0.1227 & $\mathbf{0 . 6 1 7 0}$ & $\mathbf{0 . 6 1 7 9}$ & $\mathbf{0 . 6 1 6 1}$ & 1 & $\mathbf{0 . 6 0 4 8}$ & $\mathbf{- 0 . 8 2 1 3}$ \\
P-7 & -0.2472 & -0.3523 & $\mathbf{0 . 9 3 8 5}$ & $\mathbf{0 . 9 3 8 5}$ & $\mathbf{0 . 9 3 8 1}$ & 0.6048 & 1 & -0.1806 \\
P-25 & -0.1406 & -0.3095 & -0.3329 & -0.3340 & -0.3326 & $\mathbf{- 0 . 8 2 1 3}$ & -0.1806 & 1 \\
\hline
\end{tabular}

Values in bold are different from 0 with a significance level alpha $=0.05 . \mathrm{P}=$ quality indicator: $\mathrm{P}-1=1000$ grain weight (g); P-2 = total N (\% dm); P-3 = total proteins (\%dm); P-4 = NIR-HD grain hardness; P-5 = total pentosans TP $(\% \mathrm{dm}) ; \mathrm{P}-6=$ soluble pentosans SP $(\% \mathrm{dm}) ; \mathrm{P}-7=$ vitreosity $(\%) ; \mathrm{P}-25=$ limit of attenuation $(\%)$

\subsection{Malt Quality Tests}

Analyses of malt quality indicators were done accordingly to EBC [9] and MEBAK [10], and are shown in Table 3. The analyses were conducted at the Slovenian Institute of Hop Research and Brewing, SI-3310 Žalec. Total and soluble pentosans were determined at the Max Rubner Institut, D-32758 Detmold. 
Table 3. Analysis of micromalting indicators (moisture and losses during malt production).

\begin{tabular}{cccccccc}
\hline & \multicolumn{7}{c}{ Variety } \\
\cline { 2 - 7 } & $\mathbf{1}$ & $\mathbf{2}$ & $\mathbf{3}$ & $\mathbf{4}$ & $\mathbf{5}$ & $\mathbf{6}$ & $\mathbf{7}$ \\
\hline Moisture after 48 h (\%) & $44.9^{\mathrm{ab}}$ & $44.6^{\mathrm{abc}}$ & $44.3^{\mathrm{bc}}$ & $45^{\mathrm{a}}$ & $45^{\mathrm{a}}$ & $44.3^{\mathrm{bc}}$ & $44.1^{\mathrm{c}}$ \\
\hline $\begin{array}{c}\text { Moisture at the beginning of } \\
\text { germination phase (\%) }\end{array}$ & $44.5^{\mathrm{a}}$ & $44.5^{\mathrm{a}}$ & $44.5^{\mathrm{a}}$ & $44.5^{\mathrm{a}}$ & $44.5^{\mathrm{a}}$ & $44.5^{\mathrm{a}}$ & $44.5^{\mathrm{a}}$ \\
\hline Moisture of green malt (\%) & $44.12^{\mathrm{a}}$ & $43.89^{\mathrm{a}}$ & $43.15^{\mathrm{b}}$ & $44.22^{\mathrm{a}}$ & $43.78^{\mathrm{b}}$ & $43.65^{\mathrm{b}}$ & $43.8^{\mathrm{b}}$ \\
\hline Moisture of malt (\%) & $4.58 \mathrm{~d}$ & $5.18^{\mathrm{a}}$ & $4.78^{\mathrm{b}}$ & $5.13^{\mathrm{a}}$ & $4.7^{\mathrm{c}}$ & $4.62^{\mathrm{d}}$ & $4.82^{\mathrm{b}}$ \\
\hline Total losses (g/d.wt.) & $8.9^{\mathrm{a}}$ & $8.1^{\mathrm{d}}$ & $7.5^{\mathrm{e}}$ & $8.2^{\mathrm{cd}}$ & $8.3^{\mathrm{bc}}$ & $7.6^{\mathrm{e}}$ & $8.4^{\mathrm{b}}$ \\
\hline Respiration losses (g/d.wt.) & $3^{\mathrm{b}}$ & $3.1^{\mathrm{a}}$ & $2.3^{\mathrm{e}}$ & $2.8^{\mathrm{d}}$ & $3.1^{\mathrm{a}}$ & $2.9^{\mathrm{c}}$ & $2.9^{\mathrm{c}}$ \\
\hline Germination losses (g/d. wt.) & $5.9^{\mathrm{a}}$ & $5^{\mathrm{e}}$ & $5.2^{\mathrm{d}}$ & $5.4^{\mathrm{c}}$ & $5.2^{\mathrm{d}}$ & $4.7^{\mathrm{f}}$ & $5.8^{\mathrm{b}}$ \\
\hline
\end{tabular}

Values are the mean obtained with three measurements. Values displayed in the same lines and tagged with different letters $(\mathrm{a}-\mathrm{g})$ are significantly different $(p<0.05)$.

\subsection{Experimental Design and Statistical Analysis}

Data analysis: Differences between the average values of the raw materials, micromalting, and finished malt quality indicators were analyzed using the analysis of variance (ANOVA) and Fisher's least significant difference test (LSD), with a statistical significance set at $p<0.05$. The same parameters were subjected to correlation analysis (Pearson's correlation test) to determine their possible statistically meaningful relationships. Statistical analysis was carried out using Statistica Ver. 8.0 StatSoft Inc. Tulsa, OK, USA.

\section{Results and Discussion}

Wheat samples were declared as red, winter hard varieties and all differed according to the protein share, vitreosity, and 1000 grain weight (Table 1). The starting wheat intended for malt production can be, according to quality indicators, described as soft wheat varieties with low protein content.

Correlations between the quality indicators are shown in Table 2 . The difference in 1000 grain weight was not expected since the grains were sieved $(\varnothing 2.8 \mathrm{~mm}$ and $ø 2.4 \mathrm{~mm}$ ). The expected strong correlation (Table 2) was confirmed between the total protein share and NIR grain hardness, while the correlation between total pentosans and NIR hardness was somewhat lower. These are not unusual results for hard wheat [12]. A high correlation (Table 2) between total pentosans and vitreosity was also determined, but a correlation between soluble pentosans and vitreosity was not found. No significant correlation between the total and soluble pentosans was detected. Water-soluble pentosans of wheat exhibit some unique physical properties; it is also known that soluble pentosan content has an influence on the wort viscosity and membrane filterability $(r=0.98)[5,13,14]$. As can be noted from Table 1 , the sums of the total and soluble pentosan values were within the average values for this type of wheat $[15,16]$, only sample 6 had a somewhat higher, but acceptable value $(0.82 \%$ d.wt.). Low to medium negative correlation was determined between the LAT values and all other parameters.

The major indicator of a successful malting process is obtaining wort with a low viscosity and low soluble $\mathrm{N}$ share. Considering the values obtained for moisture $48 \mathrm{~h}$ after micromalting (Table 3 ), certain significant differences between varieties could be observed. This indicator represents the criteria for swelling capacity and reflects all of the biochemical processes during malting. This indicator is significantly bound to the soaking speed and the maximal amount of water a grain can withhold. The ability to quickly absorb water and withhold larger amounts of water indicates a quicker germination (quicker activation of the aleuron layer means subsequently quicker de novo enzyme synthesis and immobilization of the existing enzymes). The ability to absorb larger amounts of water leads to more intense swelling and breakage of starch granules, which enables easier enzyme degradation, thus variety shows higher enzymatic power [10]. The obtained values were significantly $>30 \%$, the minimal 
value a grain should show after soaking. The third soaking moisture is a valuable information for maltsters, because it represents the maximal water amount a grain (under given process conditions) can soak up. The biggest decrease of viscosity can be obtained during germination of wheat (according to the standard MEBAK procedure with soaking temperature being $14^{\circ} \mathrm{C}$ ) with a third soaking moisture of $41-45 \%$. It should be clear that the moisture should not fall under $43 \%$ for green malt [17], and this was achieved for all samples (Table 3). The viscosity of wort is an indirect indicator of cytolysis. Strong cytolysis is often accompanied with increased proteolysis that needs to be contained. The tested varieties had $>12.5 \%$ of total proteins. Since the process parameters cannot be modified during the micromalting, and in order to obtain the satisfactory values for proteolytic activity (soluble N; Kolbach number 35-38\%) [17,18], steeping should be conducted with lower moisture content, which ultimately effects the process of citolysis. The obtained results for soluble $\mathrm{N}$ were satisfactory (Table 5), so there was no need to lower the moisture content in the grains, thus acting favorably on the citolytic aspect of grain modification.

Higher soaking speed and higher maximal amount of absorption result in higher losses during malting because small molecules become spent (glucose) due to the more intense breathing and germination. This is why the negative correlation between the third soaking moisture and LAT was not surprising (Table 4). Looking at other indicators, a positive correlation between the moisture of green malt and total losses was established, and a somewhat weaker correlation was established with respiration losses.

Table 4. Correlation between micromalting indicators and limit of attenuation (LAT) for the test wheat (Pearson correlation matrix).

\begin{tabular}{cccccccccc}
\hline & P-8 & P-9 & P-10 & P-11 & P-12 & P-13 & P-14 & P-15 & P-25 \\
\hline P-8 & 1 & -0.1015 & 0.0381 & -0.0799 & 0.6942 & 0.3189 & 0.0639 & -0.0528 & -0.5376 \\
P-9 & -0.1015 & 1 & $\mathbf{- 0 . 0 7 1 0}$ & -0.3688 & -0.3651 & -0.5252 & -0.5104 & -0.0815 & 0.5172 \\
P-10 & 0.0381 & -0.0710 & 1 & $\mathbf{0 . 5 2 4 3}$ & -0.1711 & -0.6357 & 0.0751 & -0.6745 & 0.2412 \\
P-11 & -0.0799 & -0.3688 & 0.5243 & 1 & $\mathbf{- 0 . 4 0 8 4}$ & -0.0905 & 0.2503 & -0.4286 & -0.2724 \\
P-12 & 0.6942 & -0.3651 & -0.1711 & -0.4084 & 1 & $\mathbf{0 . 6 3 2 4}$ & 0.1425 & $\mathbf{0 . 5 0 2 1}$ & -0.6043 \\
P-13 & 0.3189 & -0.5252 & -0.6357 & -0.0905 & 0.6324 & 1 & $\mathbf{0 . 2 8 9 4}$ & $\mathbf{0 . 7 5 5 4}$ & $\mathbf{- 0 . 8 3 2 7}$ \\
P-14 & 0.0639 & -0.5104 & 0.0751 & 0.2503 & 0.1425 & 0.2894 & 1 & $\mathbf{- 0 . 0 9 3 7}$ & -0.0971 \\
P-15 & -0.0528 & -0.0815 & -0.6745 & -0.4286 & 0.5021 & 0.7554 & -0.0937 & 1 & -0.5086 \\
P-25 & -0.5376 & 0.5172 & 0.2412 & -0.2724 & -0.6043 & -0.8327 & -0.0971 & -0.5086 & 1 \\
\hline
\end{tabular}

Values in bold are different from 0 with a significance level alpha $=0.05 ; \mathrm{P}=$ quality indicator: $\mathrm{P}-8=$ first soaking moisture (\%); P-9 = second soaking moisture (\%); P-10 = third soaking moisture (\%); P-11 = moisture of green malt $(\%)$; P-12 = moisture of malt (\%); P-13 = total losses (g dm); P-14 = respiration losses (g. dm); P-15 = germination losses (g. dry wt.); P-25 = limit of attenuation (\%).

Although the results of wheat malt quality cannot be categorized as easily as barley malt, there were values that agreed with the specification in the literature $[3,18,19]$. The quality indicators shown in Table 5 served as an assessment of the influence of each quality indicator on LAT (P16-P30). Group influences on LAT were also considered (total/soluble proteins, total proteins/Kolbach index, viscosity/filtration rate/extract difference, etc.) and correlations between the other parameters were also investigated (Table 6). 
Table 5. Results of the malt analysis.

\begin{tabular}{|c|c|c|c|c|c|c|c|}
\hline \multirow{2}{*}{ Quality indicator } & \multicolumn{7}{|c|}{ Variety } \\
\hline & 1 & 2 & 3 & 4 & 5 & 6 & 7 \\
\hline Moisture (\%) & $4.58^{\mathrm{d}}$ & $5.18^{\mathrm{a}}$ & $4.78^{b}$ & $5.13^{\mathrm{a}}$ & $4.7^{\mathrm{c}}$ & $4.62^{d}$ & $4.82^{b}$ \\
\hline 1000 grain weight (g d.wt.) & $31.7^{c}$ & $32.1 \mathrm{bc}$ & $34.4^{\mathrm{a}}$ & $34.6^{\mathrm{a}}$ & $34.2^{\mathrm{a}}$ & $29.9^{\mathrm{d}}$ & $32.2^{b}$ \\
\hline Vitreosity (\%) & $2^{g}$ & $16^{\mathrm{b}}$ & $6^{\mathrm{e}}$ & $18^{\mathrm{a}}$ & $12^{c}$ & $10^{\mathrm{d}}$ & $3^{f}$ \\
\hline Total proteins (\% d.wt.) & $14.66^{c}$ & $12.68^{\mathrm{e}}$ & $14.68^{c}$ & $15.37^{b}$ & $15.68^{a}$ & $14.8^{\mathrm{c}}$ & $12.38^{\mathrm{d}}$ \\
\hline Total N (g/100 g d.wt.) & $2.32^{c}$ & $2.03^{d}$ & $2.35^{b c}$ & $2.46^{\mathrm{a}}$ & $2.51^{\mathrm{a}}$ & $2.37^{b}$ & $2.3^{c}$ \\
\hline Coarse extract content (\% d.wt.) & $81.7^{\mathrm{b}}$ & $83.9^{\mathrm{a}}$ & $81.1^{b c}$ & 81 bcd & $79.8^{\mathrm{d}}$ & $80.2^{\mathrm{cd}}$ & $80 \mathrm{~cd}$ \\
\hline Fine extract content (\% d.wt.) & $83.1^{\mathrm{b}}$ & $85.9^{\mathrm{a}}$ & $82.1^{b c}$ & $82.1^{b c}$ & $80.9^{c}$ & $82.3^{b}$ & $82.1^{b c}$ \\
\hline Extract difference (\%d.wt.) & $1.4^{\mathrm{c}}$ & $2^{b}$ & $1^{\mathrm{e}}$ & $1.1^{\mathrm{d}}$ & $1.1^{\mathrm{d}}$ & $2.1^{a}$ & $2.1^{a}$ \\
\hline Saccharification time (min) & $\leq 10$ & $\leq 10$ & $\leq 15$ & $\leq 10$ & $\leq 10$ & $\leq 15$ & $\leq 10$ \\
\hline Clarity of wort (EBC u.) & clear & clear & clear & clear & clear & clear & clear \\
\hline Wort color (EBC u.) & $4^{\mathrm{e}}$ & $4.6^{\mathrm{d}}$ & $3.7^{f}$ & $4.7^{c}$ & $5.1^{\mathrm{a}}$ & $3.1^{\mathrm{g}}$ & $4.8^{b}$ \\
\hline Color after cooking (EBC u.) & $6.6^{\mathrm{d}}$ & $7.3^{c}$ & $5.6^{\mathrm{e}}$ & $7.7^{b}$ & $8.7^{\mathrm{a}}$ & $4.8^{\mathrm{f}}$ & $6.6^{\mathrm{d}}$ \\
\hline Filtration time (min) & $40^{\mathrm{b}}$ & $45^{\mathrm{a}}$ & $35^{c}$ & $35^{c}$ & $30^{d}$ & $40^{\mathrm{b}}$ & $40^{b}$ \\
\hline $\mathrm{pH}$ of wort & $6.12^{\mathrm{ab}}$ & $6.17^{a}$ & $6.13^{a b}$ & $6.05^{b}$ & $6.05^{b}$ & $6.14^{a b}$ & $6.18^{a}$ \\
\hline Viscosity (mPas. 8.6\%e) & $1.477^{b c d}$ & $\begin{array}{c}1.481 \\
\mathrm{bc}\end{array}$ & $1.495^{b}$ & $1.457^{\mathrm{d}}$ & $\begin{array}{c}1.466 \\
\mathrm{~cd}\end{array}$ & $1.545^{\mathrm{a}}$ & $1.458^{\mathrm{d}}$ \\
\hline Hartong number. VZ $45^{\circ} \mathrm{C}(\%)$ & $36^{c}$ & $38.3^{b}$ & $32.9^{\mathrm{e}}$ & $41.5^{\mathrm{a}}$ & $41.8^{a}$ & $34.4^{\mathrm{d}}$ & $31.1^{\mathrm{f}}$ \\
\hline Diastatic power $\left({ }^{\circ} \mathrm{WK}\right)$ & $250^{b c}$ & $250^{b c}$ & $248^{c d}$ & $266^{a}$ & $264^{a}$ & $245^{d}$ & $253 b$ \\
\hline Final attenuation of wort (\%) & $82.55^{b c}$ & $83.5^{\mathrm{b}}$ & $85.36^{\mathrm{a}}$ & $81.03^{\mathrm{d}}$ & $81.9^{\mathrm{cd}}$ & $\underset{\mathrm{bc}}{82.58}$ & $82.8 \mathrm{bc}$ \\
\hline Soluble N (mg/L) & $805^{d}$ & $735^{\mathrm{e}}$ & $854^{b}$ & $917^{a}$ & $924^{a}$ & $847^{b}$ & $824 \mathrm{c}$ \\
\hline Soluble N (g/100 g dry wt.) & $0.72^{c}$ & $0.66^{d}$ & $0.76^{\mathrm{b}}$ & $0.82^{a}$ & $0.83^{a}$ & $0.76^{b}$ & $0.77 \mathrm{~b}$ \\
\hline HM N/soluble N (\%) & $50.3^{b}$ & $49.1^{\mathrm{c}}$ & $53.8^{\mathrm{a}}$ & $48.3^{d}$ & $50.4^{\mathrm{b}}$ & $49.2^{c}$ & $53.5^{\mathrm{a}}$ \\
\hline FAN (mg/100 g dry wt.) & $115.4^{c}$ & $110.7^{\mathrm{d}}$ & $110^{d}$ & $143.8^{\mathrm{a}}$ & $139.5^{b}$ & $107.1^{\mathrm{e}}$ & $114.3^{c}$ \\
\hline Formol N (mg/L) & $351^{\mathrm{e}}$ & $358^{d}$ & $348^{f}$ & $389^{b}$ & $392^{a}$ & $364^{c}$ & $341^{g}$ \\
\hline Formol N (mg/g d. wt.) & $332.1^{\mathrm{e}}$ & $389.4^{\mathrm{a}}$ & $327.5^{\mathrm{g}}$ & $356.4^{c}$ & $362.8^{b}$ & $340.2^{d}$ & $329.3^{f}$ \\
\hline Kolbach index (\%) & $31^{\mathrm{e}}$ & $32.6^{b c}$ & $32.3^{\mathrm{cd}}$ & $33.6^{a}$ & $33^{b}$ & $31.9^{\mathrm{d}}$ & $32.1^{\mathrm{d}}$ \\
\hline
\end{tabular}

Values are the mean obtained with three measurements. Values displayed in the same lines and tagged with different letters $(\mathrm{a}-\mathrm{g})$ are significantly different $(p<0.05)$ 
Table 6. Correlation between wheat malt quality indicators and limit of attenuation (Pearson correlation matrix).

\begin{tabular}{|c|c|c|c|c|c|c|c|c|c|c|c|c|c|c|c|}
\hline Variables & P-16 & P-17 & P-18 & P-19 & P-20 & P-21 & P-22 & P-23 & P-24 & P-25 & P-26 & P-27 & P-28 & P-29 & P-30 \\
\hline P-16 & 1 & 0.3999 & -0.3496 & -0.8317 & 0.5621 & -0.6169 & -0.6517 & 0.4460 & 0.7063 & 0.0057 & 0.5179 & 0.1953 & 0.6794 & 0.1077 & 0.6741 \\
\hline P-17 & 0.3999 & 1 & 0.9456 & 0.5953 & & & -0.0814 & 0.28 & & -0.4 & & & & & \\
\hline P-18 & -0.3496 & -0.9456 & 1 & 0.4681 & -0.0 & 0.56 & 0.0702 & -0.0182 & -0 & 0.26 & -0.9 & -0 . & -0.46 & 0.5 & -0.1655 \\
\hline P-19 & - & -0.5 & 0.4681 & 1 & -0.1927 & 0.78 & 0.3561 & -0.4680 & -0 . & 0.0063 & -0.5221 & -0 . & -0.6075 & & 3558 \\
\hline P-20 & 0.5621 & 0.0525 & -0.0456 & -0.1927 & 1 & -0.3096 & -0.8965 & 0.5047 & 0.7 & -0.4163 & 0.2709 & -0.0 & 0.6616 & 0.46 & 0.5497 \\
\hline $\mathrm{P}-21$ & -0.6169 & -0.7766 & 0.5632 & 0.7810 & -0.3096 & 1 & 0.2886 & -0.7945 & -0.8031 & 0.5699 & -0.7417 & 0.4084 & -0.8907 & -0.1457 & -0.5567 \\
\hline P-22 & -0.6517 & -0.0814 & 0.0702 & 0.3561 & -0.8965 & 0.2886 & 1 & -0.3403 & -0.7100 & 0.3146 & -0.2403 & -0.1325 & -0.6098 & -0.1727 & -0.3817 \\
\hline P-23 & 0.4460 & 0.2803 & -0.0182 & -0.4680 & 0.5047 & -0.7945 & -0.3403 & 1 & 0.7640 & -0.6209 & 0.3167 & -0.7297 & 0.8079 & 0.6984 & 0.6436 \\
\hline P-24 & 0.7063 & 0.5560 & -0.4174 & -0.5414 & 0.7727 & -0.8031 & -0.7100 & 0.7640 & 1 & -0.6869 & 0.6988 & -0.3015 & 0.9844 & 0.3259 & 0.7563 \\
\hline P-25 & 0.0057 & -0.4441 & 0.2633 & 0.0063 & -0.4163 & 0.5699 & 0.3146 & -0.6209 & -0.6869 & 1 & -0.4841 & 0.6647 & -0.7167 & -0.2487 & -0.3417 \\
\hline P-26 & 0.5179 & 0.9423 & -0.9200 & -0.5221 & 0.2709 & -0.7417 & -0.2403 & 0.3167 & 0.6988 & -0.4841 & 1 & 0.0516 & 0.7364 & -0.2724 & 0.5085 \\
\hline P-27 & 0.1953 & 0.0186 & -0.3054 & -0.0663 & -0.0242 & 0.4084 & -0.1325 & -0.7297 & -0.3015 & 0.6647 & 0.0516 & 1 & -0.3775 & -0.6387 & -0.2990 \\
\hline P-28 & 0.6794 & 0.6411 & -0.4680 & -0.6075 & 0.6616 & -0.8907 & -0.6098 & 0.8079 & 0.9844 & -0.7167 & 0.7364 & -0.3775 & 1 & 0.2880 & 0.7222 \\
\hline P-29 & 0.1077 & -0.4140 & 0.5659 & 0.1058 & 0.4626 & -0.1457 & -0.1727 & 0.6984 & 0.3259 & -0.2487 & -0.2724 & -0.6387 & 0.2880 & 1 & 0.5410 \\
\hline P-30 & 0.6741 & 0.2690 & -0.1655 & -0.3558 & 0.5497 & -0.5567 & -0.3817 & 0.6436 & 0.7563 & -0.3417 & 0.5085 & -0.2990 & 0.7222 & 0.5410 & 1 \\
\hline
\end{tabular}

Values in bold and underlined are different from 0 with a significance level alpha $=0.05 ; \mathrm{P}=$ quality indicator: $\mathrm{P}-16=1000 \mathrm{grain}$ weight $(\mathrm{g} \mathrm{dm}) ; \mathrm{P}-17=\mathrm{total} \mathrm{N}(\mathrm{g} / 100 \mathrm{~g} \mathrm{dm}) ; \mathrm{P}-18=$ fine extract content $(\% \mathrm{dm}) ; \mathrm{P}-19=$ extract difference $(\% \mathrm{dm}) ; \mathrm{P}-20=$ wort color $\left(\mathrm{EBC}\right.$ unit); P-21 = pH of wort; P-22 = viscosity (mPas, $8.6^{\circ} \%$ ); P-23 = Hortong number VZ45 ${ }^{\circ} \mathrm{C}(\%) ; \mathrm{P}-24=$ diastatic power $\left({ }^{\circ} \mathrm{WK}\right) ; \mathrm{P}-25=$ limit of attenuation $(\%) ; \mathrm{P}-26=$ soluble N (g/100 g dm); P-27 = HM N/soluble N (\%); P-28 = FAN (mg/100 g dm); P-29 = formol N (mg/g dm); P-30 = Kolbach index $(\%)$. 
A 1000 grain weight was a mediocre value for all of the tested varieties and showed no significant correlation with any of the other indicators. This is why it was not considered for further investigation. In comparison to the starting vitreosity of wheat, malt grain, and starting wheat grain, it can be noted that varieties 1, 3, and 7 possessed temporary vitreosity (mealy varieties) while malts obtained from varieties 2, 4, 5, and 6 showed partial permanent vitreosity. Significant correlations were obtained for values of diastatic power, formol N, and Kolbach indexes. The share of fine extract should be as high as it can, certainly $>83 \%(83-85 \%)$ [3]. Varieties 1 and 2 were satisfactory; varieties 3, 4, 6, and 7 showed somewhat lower values and variety 5 resulted in low fine extract values. Considering that the extract difference results showed as being very good, these fine extract values can be attributed to the increased protein share. This is especially pronounced in the comparison between varieties 2 and 5. The F/G difference is an indicator of successful endosperm cell wall degradation. High values of $\mathrm{F} / \mathrm{G}$ mean that the endosperm is not well degraded and a lower share of fermentable sugars can be expected in such malts. Even though a slight, but clear difference was noted between samples 1, 3, 4, 5 and 2,6,7, the obtained values were satisfactory for all varieties. Significant positive correlations were obtained for filtration time and wort $\mathrm{pH}$. Negative correlation was determined between 1000 grain weight. Saccharification time was within the recommended limits of 10-15 min. Wort $\mathrm{pH}$ for all samples was somewhat higher than recommended (5.9-6.1), except for samples 4 and 5. The negative correlation was determined between the total proteins, $\mathrm{VZ} 45^{\circ} \mathrm{C}$, diastatic power, soluble $\mathrm{N}$, FAN, and formol N. This strong negative correlation between proteolytic and cytolytic parameters was expected because the protein degradation results in free amino acids that react with sugars in water solution and produce acidic melanoidins, lowering the $\mathrm{pH}$ value of wort. On the other hand, protein degradation is conditioned by a lower $\mathrm{pH}$. The already mentioned positive correlation with the F/G difference was a result of lower endosperm degradation during mashing, and resulted in less accessible substrate for the aforementioned reactions. A strong positive correlation was determined with filtration time, also easily explainable with the lower degradation of endosperm. The color and the color after cooking were within the recommended values for all samples, except for sample 5, while samples 2, 4, and 5 had increased values for this parameter. Proteolytic events and the parameters that measure their successfulness should mostly influence the color, especially FAN [18,20]. However, the strong correlation was obtained only with the viscosity of wort and diastatic power. The viscosity of wort gives an insight into the cytolytic degradation of malt. Wort viscosity and its influence on the production process and beer quality has been well investigated [18,21]. The general recommendation for wheat malt is to be as low as possible, not over $1.65 \mathrm{mPa} \times \mathrm{s} 8.6 \%$. All tested samples showed excellent viscosity. It should be emphasized that a strong positive correlation was determined between color of wort, while a correlation with F/G difference, filtration time, and $\mathrm{VZ} 45^{\circ} \mathrm{C}$ (Hartong number) was lacking. All varieties had diastatic power values close to the lower limit recommendation (250-420 $\left.{ }^{\circ} \mathrm{WK}\right)$. This mostly reflects the activity of egzoenzymes for starch degradation, which increase the content of maltose in wort. The lack of positive correlation with LAT was unexpected. A strong positive correlation was established between wort color and VZ $45^{\circ} \mathrm{C}, \mathrm{FAN}$, and formol N. A negative correlation, as expected, was established with $\mathrm{pH}$. VZ $45^{\circ} \mathrm{C}$ is an indirect indicator of cytolytic and proteolytic enzyme activity that enable the production of free amino acids and lower peptides, easily assimilable by yeasts. The obtained values were satisfactory for all varieties, except for variety 7 , whose values were significantly over the recommendation to not go over the Kolbach index by 2 units. The Kolbach index should be $>33$ for malts with $12.5 \%$ total proteins. However, it should be emphasized that in this case, the worts contained a significantly higher share of proteins (except for samples 2 and 7). The expected strong correlations between diastatic power, FAN, and formol $\mathrm{N}$ were obtained. A strong negative correlation with the high molecular $\mathrm{N}$ share in the total soluble $\mathrm{N}$ was determined. According to Narziss [3], this relation should not go over $45 \%$ while the tested varieties showed a span of $48.3-53.8 \%$ (Table 5), so the obtained correlation is not surprising. This increase of high-molecular $\mathrm{N}$ (potentially damaging $\mathrm{N}$ for colloidal stability and useless for yeast [5]) indicates a low proteolysis. Total proteins have a central role in the quality and structure of wheat malt. They 
influence the reduction of the extract and the increase in soluble $\mathrm{N}$ and low-molecular $\mathrm{N}$ (formol $\mathrm{N}$ and FAN) [18]. $\mathrm{N}$ fractions are mostly non-fermentable, so the increase in total $\mathrm{N}$ should lead to reduced LAT. Sacher [18], however, established that the increase of total proteins acts by decelerating their degradation. This causes an extremely slow increase of soluble $\mathrm{N}$ with the increase of total protein content in the grain. The quotient of these two values may also have a downward trend. It has already been mentioned that the tested assortment showed increased values for total proteins. The recommended values (12-13\% d.wt.) were only detected in sample 2 . Wheat samples mostly differed among each other considering the total protein content (Table 1) and protein degree of degradation during malting $(\Delta \mathrm{m}$ total proteins in wheat: wheat malt $1=0.78 \% ; 2=1.2 \% ; 3=0.57 \% ; 4=1.01 \%$; $5=0.45 \% ; 6=0.7$, and $7=1.99 \%$ ). No significant correlation was established between the content of total proteins, their reduction during malting, and total losses during malting. According to the literature, soluble $\mathrm{N}$ values can range from 700-900 mg/100 g d.wt.; [9], 700-770 mg/100 g d.wt., [3]; $<730 \mathrm{mg} / 100 \mathrm{~g}$ d.wt.; [18]. All tested samples were below $<900 \mathrm{mg} / 100 \mathrm{~g} \mathrm{~d} . w \mathrm{t}$, and only samples 4 and 5 were above $770 \mathrm{mg} / 100 \mathrm{~g}$ d.wt. Samples 1 and 2 showed excellent values regarding this indicator. It can be stated that the tested assortment showed the effect of proteolysis deceleration and saturation. The expected strong negative correlation was established for fine and coarse extracts. A strong positive correlation was detected for soluble N, but not with other indicators of proteolysis efficiency. Positive correlation was established between soluble $\mathrm{N}$ and FAN, and a strong negative correlation with fine and coarse extracts. The expected strong correlation between soluble $\mathrm{N}$ and $\mathrm{VZ} 45^{\circ} \mathrm{C}$ was neglected. A negative correlation between high-molecular $\mathrm{N}$ and FAN was established. The soluble N/FAN quotient indicates how well the soluble proteins are degraded. In wheat malt, this quotient should be much lower (9-16\%) than in barley malt (19-24\%). FAN was within the recommended values for all samples. Formol $\mathrm{N}$ represents the low-molecular $\mathrm{N}$ obtained by the degradation of amino acids and lower peptides and was inside the recommended values for all samples. Its strong positive correlation with FAN, diastatic power, and VZ $45^{\circ} \mathrm{C}$ was established. The Kolbach index represents the share of soluble $\mathrm{N}$ in total $\mathrm{N}$ and is an indicator of successful proteolytic malt degradation. The Kolbach index for wheat malt should be $>38$. All samples showed significantly lower values because of the aforementioned lower soluble $\mathrm{N}$ with regard to the starting total proteins. There was a strong positive correlation between Kolbach index, vitreosity, and the malts' diastatic power.

The limit of attenuation of wort was very good for all samples, above the recommended $81.5 \%$; according to other literature sources [3], samples 2 and 3 showed somewhat higher values than 78-81\%. Although the correlation analysis showed no strong correlations between LAT and all other indicators (Table 6), it is obvious that the quality indicators of malt (extract, extract difference, $\mathrm{VZ} 45^{\circ} \mathrm{C}$, diastatic power, and soluble $\mathrm{N}$ fractions) act significantly, and even crucially on LAT. It is reasonable to assume that the lack of narrow correlations with an individual malt quality indicator is due to the mutual intertwining of indicators and their final cumulative effect on LAT. The complexity of this intertwining indicates that LAT should be observed individually as a variety trait.

\section{Conclusions}

This research investigated wheats and malts with the aim to determine the intensity of individual malt quality indicators on the limit of attenuation of wort (LAT). Respectively, the strength of correlation between LAT and the other quality indicators of malt was assessed. All malt samples had an increased share of total proteins, total $\mathrm{N}$, and were classified as the second malting group. No practical correlation between LAT and other quality indicators was established. This points to the fact that this parameter should be observed as an individual quality indicator and mainly as a variety trait. The obtained results indicate that further research regarding the studied quality indicators and their influence on finished beer should be conducted.

Author Contributions: Conceptualization, V.K.; Methodology, V.K.; Data curation, K.M.; Writing-original draft preparation, K.H.; Writing-review and editing, V.N.; Supervision, V.K. 
Funding: This research received no external funding.

Conflicts of Interest: The authors declare no conflicts of interest.

\section{References}

1. Brandam, C.; Meyer, X.M.; Proth, J.; Strehaiano, P.; Pingaud, H. An original kinetic model for the enzymatic hydrolysis of starch during mashing. Biochem. Eng. J. 2003, 13, 43-52.

2. Hagenand, W.; Schwarz, H. Determination of fermentability (finalattenuation) of wort. J. Inst. Brew. 1999, $105,73-74$.

3. Narziss, L.; von Spezieler, T.M. In Die Bierbrauerei: Band I: Die Technologie Der Malzbereitung, 7th ed.; Schuster, K., Weinfurtner, F., Narziss, L., Eds.; Wiley-VCH: Stuttgart, Germany, 1999.

4. Flavours of Wheat Beers. Available online: https://cdn.uclouvain.be/public/Exports\%20reddot/inbr/ documents/Zarnkow_Wheat_Flavour_Louvain_2008.pdf (accessed on 12 August 2019).

5. Faltermaier, A.; Waters, D.; Becker, T.; Arendt, E.; Gastl, M. Common wheat (Triticum aestivum L.) and its use as a brewing -A review. J. Inst. Brew. 2014, 120, 1-15. [CrossRef]

6. Tabatabaei, S. A The changes of germination characteristics and enzyme activity of barley seeds under accelerated aging. Cercet. Agron. Mold. 2015, 48, 62-67. [CrossRef]

7. Krstanović, V. Research of Malting Procedures for Domestic Wheat Varieties. Ph.D. Thesis, University of Zagreb, Zagreb, Croatia, 7 October 2004.

8. Unbehend, L.; Unbehend, G.; Lindhauer, M.G. Comparison of the quality of some Croatian and German wheat varieties according to the German standard protocol. Nahr. Food 2003, 47, 40-144. [CrossRef] [PubMed]

9. European Brewery Convention, Analytica, 5th ed.; Fachverlag Hans Carl: D-Nürnberg, Germany, 1998.

10. Middle European Brewing Analysis Commission. Brautechnische Analysenmethoden, 3rd ed.; Band I Selbstverlag der MEBAK: Freising-Weihenstephan, Germany, 1997.

11. Hashimoto, S.; Shorgen, M.; Pomeranz, Y. Cereal pentosans: Their estimation and significance. 1. Pentosans in wheat and milled wheat products. Cereal Chem. 1987, 64, 30-34.

12. Bettge, A.D.; Craig, C.F. Relationships among grain hardness, pentosan fractions, and end-use quality of wheat. Cereal Chem. 2000, 77, 241-247. [CrossRef]

13. Jian, L.; Yin, L. Effects of arabinoxylan solubilization on wort viscosity and filtration when mashing with grist containing wheat and wheat malt. Food Chem. 2006, 98, 164-170.

14. Schwarz, P.B.; Han, J.-Y. Arabinoxylan content of commercial beers. J. Am. Soc. Brew. Chem. 1995, 53, 157-159. [CrossRef]

15. Peterson, C.J.; Graybosch, R.A.; Baenziger, P.S.; Grombacher, A.W. Genotype and environment effects on quality characteristics of hard red winter wheat. Crop Sci. 1992, 32, 98-103. [CrossRef]

16. Peterson, C.J.; Graybosch, R.A.; Shelton, D.R.; Baenziger, P.S. Baking quality of hard winter wheat: Response of cultivars to environment in the Great Plains. Euphytica 1998, 100, 157-162. [CrossRef]

17. Narziss, L. Die Bierbrauerei: Band I: Die Technologie Der Malzbereitung. In Spezieler Typ von Malz, 7th ed.; F. Enke: Stuttgart, Germany, 1999.

18. Sacher, B. Trials for the Optimisation of Use of Soft-Wheat Varieties in Malting and Brewing. Ph. D. Thesis, TU München-Weihenstephan, Munich, Germany, 1998.

19. Kunze, W. Technology Brewing and Malting, 2nd ed.; VLB: Berlin, Germany, 1999.

20. Goldammer, T. Malt Products. In Technology Brewing and Malting, 3rd ed.; Kunze, W., Ed.; VLB: Berlin, Germany, 2004.

21. Sadosky, P.; Schwarz, P.B.; Horsley, R.D. Effect of arabinoxylans, beta- glucans, and dextrins on the viscosity and membrane filterability of a beer model solution. J. Am. Soc. Brew. Chem. 2002, 60, 153-162. 